\title{
Altered glutamyl-aminopeptidase activity and expression in renal neoplasms
}

\author{
Lorena Blanco ${ }^{1}$, Begoña Sanz ${ }^{1}$, Itxaro Perez ${ }^{1,2}$, Clara E Sánchez ${ }^{2}$, M Luz Cándenas ${ }^{3}$, Francisco M Pinto ${ }^{3}$, Javier Gil ${ }^{1}$, \\ Luis Casis ${ }^{1}$, José I López ${ }^{4}$ and Gorka Larrinaga ${ }^{1,2^{*}}$
}

\begin{abstract}
Background: Advances in the knowledge of renal neoplasms have demonstrated the implication of several proteases in their genesis, growth and dissemination. Glutamyl-aminopeptidase (GAP) (EC. 3.4.11.7) is a zinc metallopeptidase with angiotensinase activity highly expressed in kidney tissues and its expression and activity have been associated wtih tumour development.

Methods: In this prospective study, GAP spectrofluorometric activity and immunohistochemical expression were analysed in clear-cell (CCRCC), papillary (PRCC) and chromophobe (ChRCC) renal cell carcinomas, and in renal oncocytoma (RO). Data obtained in tumour tissue were compared with those from the surrounding uninvolved kidney tissue. In CCRCC, classic pathological parameters such as grade, stage and tumour size were stratified following GAP data and analyzed for 5-year survival.
\end{abstract}

Results: GAP activity in both the membrane-bound and soluble fractions was sharply decreased and its immunohistochemical expression showed mild staining in the four histological types of renal tumours. Soluble and membrane-bound GAP activities correlated with tumour grade and size in CCRCCs.

Conclusions: This study suggests a role for GAP in the neoplastic development of renal tumours and provides additional data for considering the activity and expression of this enzyme of interest in the diagnosis and prognosis of renal neoplasms.

Keywords: Glutamyl-aminopeptidase, Aminopeptidase A, Angiotensinase, Angiotensin, Clear cell renal cell carcinoma, Renal neoplasm

\section{Background}

Clinical data support the fact that renal cell carcinomas (RCCs) are neoplasms with high prevalence and mortality rates [1]. The 2004 WHO classification of renal tumours in adults includes newly reported entities [2] and links the classical histological findings of these neoplasms to a wide spectrum of genetic abnormalities [3] still not fully defined. Clear cell renal cell carcinoma (CCRCC) is by far the most frequent histological subtype, accounting for approximately $70 \%$ of the cases. The proximal convoluted tubule is the proposed site of origin for CCRCC. Papillary renal cell carcinoma (PRCC)

\footnotetext{
* Correspondence: gorka.larrinaga@ehu.es

${ }^{1}$ Department of Physiology, Faculty of Medicine and Dentistry, Universitiy of the Basque Country (UPV/EHU), Leioa, Bizkaia, Spain

${ }^{2}$ Department of Nursing I, Faculty of Nursing, Universitiy of the Basque Country (UPV/EHU), Leioa, Bizkaia, Spain

Full list of author information is available at the end of the article
}

is the second most frequent subtype (10\%-15\%) and also arises in the proximal convoluted tubule. Chromophobe renal cell carcinoma (ChRCC) and renal oncocytoma (RO), both of which originate from the intercalated cells of the collecting ducts in the distal nephron and are thought to share a common lineage, are much less frequent, accounting for approximately $5 \%$ of the cases each [2].

At present, there is no clinical marker to detect the disease in the asymptomatic potentially curable phase or to reliably predict the clinical course of every case. Only classic pathological parameters such as histological subtype, tumour stage and grade may contribute to that purpose. However, depending on the clinical setting and other circumstances, many renal tumours escape the expected behaviour and this means it is necessary to discover more predictable parameters [4]. 
Recent findings have revealed the implication of several proteases in the genesis, growth and dissemination of renal neoplasms. Significant effort has been made towards understanding the role of matrix metalloproteinases [4-7]. In parallel, an increasing number of studies show significant changes in the expression and activity of peptidases in these tumours and point to these proteins not only as potential diagnostic and prognostic markers but also as therapeutic targets [8-12].

Glutamyl-aminopeptidase (GAP), also known as aminopeptidase A (EC. 3.4.11.7), is a membrane-bound zinc metallopeptidase that removes $\mathrm{N}$-terminal acidic residues from peptides such as angiotenin II, its best known natural substrate [13]. GAP has a widespread tissue distribution and participates in many diverse biological processes [14]. This enzyme is involved in the development of kidney structures [14] and is expressed in the glomerulus and in the tubular system of the nephron [15], where it has been described as the gp160 human kidney differentiation antigen [16].

Immunoassay and semiquantitative enzymatic studies in renal cell carcinoma cell lines and in primary renal cancers have shown altered GAP expression and activity in these neoplasms $[8,9,17]$. It has also been reported that GAP expression is correlated with resistance to the antiproliferative effect of interferon- $\alpha$ in RCCs [18]. These data suggest that the study of GAP activity and expression may have diagnostic and prognostic applications for clinical practice. To clarify this question we quantified GAP activity and analysed its immunohistochemical expression in a wide range of renal neoplasms. We selected renal tumours with different histogenetic origins and aggressiveness (CCRCC, PRCC, ChRCC and $\mathrm{RO}$ ), which cover $95 \%$ of renal neoplasms. Additionally, the GAP activity profile was compared in different CCRCC grades and stages and was correlated with patient survival.

\section{Methods}

The authors declare that all experiments carried out in this study comply with current Spanish and European Union legal regulations. Samples and data from patients included in this study were provided by the Basque Biobank for Research-OEHUN (www.biobancovasco.org). All patients were informed about the potential use for research of their surgically resected tissues, and accepted this eventuality by signing a specific document approved by the Ethical and Scientific Committees of the Basque Country Public Health System (Osakidetza) (CEIC 11/51).

\section{Tissue specimens}

We analysed renal tissue in a series from patients with CCRCC, PRCC, ChRCC and RO. Hospital Ethics Committee approval was obtained a priori. Fresh tissue samples were obtained from surgical specimens from renal tumour patients. Tumour and normal (surrounding uninvolved tissue) areas were obtained in all cases. For activity studies, tissue samples were stored at $-80^{\circ} \mathrm{C}$ until the enzyme assays were performed. In addition, selected tissue samples were formalin-fixed and paraffinembedded for histopathological studies. The 2004 WHO histological classification of adult renal cell tumours [2] and the 2002 TNM Edition for tumour staging [19] were used for pathological diagnosis. In addition, Furhman's method [20] was applied for grading CCRCC subtype. Clinical follow up of CCRCC patients was closed by December 31, 2012, and a total of 14 patients died of disease at that time. Mean follow up was 65.2 months (range, 8-130 months).

\section{Sample preparation}

Although GAP has been classically reported as a cellsurface peptidase [16], several studies have also demonstrated GAP activity in soluble fractions of different tissues and cells [21-23]. We therefore analysed GAP activity in both membrane-bound and soluble fractions of kidney tissues.

Explanted tissue samples were homogenised in $10 \mathrm{mM}$ Tris- $\mathrm{HCl}$ buffer at $\mathrm{pH} 7.4$, for 30 seconds at $800 \mathrm{rpm}$ using a Heidolph PZR 50 Selecta homogeniser, and ultracentrifuged in a Centrikon T-2070 Kontron Instruments apparatus at 100,000 $\mathrm{g}$ for $35 \mathrm{~min}$. The resulting supernatants were used to measure cytosolic (soluble) enzyme activities and protein concentrations. To avoid contamination with soluble enzymes, the resulting pellets were washed three times by suspension in $10 \mathrm{mM}$ Tris- $\mathrm{HCl}$ buffer at $\mathrm{pH}$ 7.4. Pellets were then homogenised in $10 \mathrm{mM}$ Tris- $\mathrm{HCl}$ buffer at $\mathrm{pH} 7.4$, and centrifuged at low speed $(1500 \mathrm{~g})$ for $3 \mathrm{~min}$ to purify the samples. The supernatants thus obtained were used to determine membrane-bound enzyme activities and protein concentrations. All the aforementioned steps were carried out at $4^{\circ} \mathrm{C}$.

\section{Measurement of glutamyl-aminopeptidase activity}

The enzyme activity of tumour and non-tumour tissue samples from 50 patients with CCRCC (40 men, 10 women; mean age: 63 years), 10 patients with ChRCC (5 men, 5 women; mean age: 64 years) and 8 patients with RO (6 men, 2 women; mean age: 67 years) was analysed by spectrofluorometric methods. GAP activity was measured by a modified version of Tobe et al.'s method [24], using Glu- $\beta$-naphthylamide $(0.125 \mathrm{mM})$ as a substrate. The assay is based on the fluorescence of $\beta$-naphthylamine generated from the substrate by GAP. The components of the assay mixture (total volume $2 \mathrm{~mL}$ ) included the following: $50 \mathrm{mM}$ of Tris $-\mathrm{HCl}$ buffer $(\mathrm{pH} 7.4)$ and $0.15 \mathrm{mg} / \mathrm{mL}$ of bovine serum albumin. The 
reaction was initiated by adding $30 \mu \mathrm{L}$ of sample to $1 \mathrm{~mL}$ of the assay mixture. This was incubated at $37^{\circ} \mathrm{C}$ for $30 \mathrm{~min}$ and the reaction was discontinued by the addition of $1 \mathrm{~mL}$ of $0.1 \mathrm{M}$ sodium acetate buffer ( $\mathrm{pH}$ 4.2). The excitation and emission wavelengths were 345 and $412 \mathrm{~nm}$, respectively. Blanks were used to determine background fluorescence. Relative fluorescence was converted into picomoles of product using a standard curve constructed with increasing concentrations of $\beta$-naphthylamine.

Protein concentration was measured in triplicate by the Bradford method [25], using BSA $(1 \mathrm{mg} / \mathrm{mL})$ as the calibrator. Results were recorded as units of peptidase (UP) per milligram of protein. One unit is equivalent to the release of one mole of beta-naphthylamine per minute. Fluorogenic assays were linear with respect to hydrolysis time and protein content.

\section{Immunohistochemistry}

Formalin-fixed and paraffin-embedded tumour tissue from 12 CCRCC ( 9 men and 3 women; mean age: 62 years); 6 PRCC ( 5 men and 1 woman; mean age: 64 years), 4 ChRCC ( 2 men, 2 women; mean age: 67 years) and 4 RO (all men, mean age: 63 years) were immunostained with a rabbit polyclonal antibody specific for glutamyl-aminopeptidase (Anti BP-1, Abcam plc, Cambridge, UK, working diluton 1:250). The immunostaining process was performed following routine methods in an automatic immunostainer (Dako Autostainer Plus). In short, endogenous peroxidase activity was blocked by incubating the slides in 3\% hydrogen peroxide in absolute methanol for 10 minutes. Antigen retrieval was carried out in citrate buffer $(10 \mathrm{mM}, \mathrm{pH}=6)$ for 15 minutes at $100^{\circ} \mathrm{C}$ in a microwave oven. The primary antibody was applied for 1 hour at room temperature. A subsequent reaction was performed with secondary antibodies and biotin-free HRP enzyme labelled polymer of the EnVision-Flex detection system (Dako, Carpinteria, CA). Nonspecific IgG was used as a negative control. A positive reaction was visualized with diaminobenzydine solution followed by counterstaining with haematoxylin. Two independent observers analysed the immunohistochemical slides separately assigning staining intensity according to a semiquantitative scale [(negative $(-)$, mild $(+)$, moderate $(++)$, and intense $(+++)]$. Minor disagreements were reconciled under a multihead microscope.

\section{Quantitation of GAP (ENPEP) mRNA expression}

Quantitative RT-PCR for detecting ENPEP mRNA was performed to assess the transcription levels of this enzyme. The total RNA of tumour tissue samples from 30 CCRCC patients (18 male, 12 female; mean age: 62 years) was isolated following the standard protocol previously described [26].

First-strand cDNA was synthesized from $25 \mu \mathrm{g}$ of total RNA from each human sample using Moloney murine leukemia virus reverse transcriptase and random hexamers according to the manufacturer's instructions (firststrand cDNA Synthesis Kit, Amersham Biosciences, Essex, UK). The resulting cDNA samples were amplified by PCR with specific oligonucleotide primer pairs designed with the analysis software Primer 3 [27]. Based on previous experiments on human renal cell carcinoma [28] and other human tissues $[29,30]$, TATA box binding protein $(T B P)$, peptidylprolyl isomerase A (PPIA), $\beta$-actin $(A C T B)$ and succinate dehydrogenase complex subunit $\mathrm{A}$ $(S D H A)$ were chosen as endogenous reference genes. The sequences of the primers used to amplify ENPEP and the four housekeeping genes are shown in Table 1. All primers were synthesized and purified by Sigma-Genosys (Cambridge, UK).

Expression of the target and housekeeping genes was quantified in all cDNAs by real-time PCR using the iCycler iQ real-time detection apparatus (BioRad Laboratories, Hercules, CA, USA). Dilutions of the cDNA template were prepared with each tissue and amplified in triplicate using SensiMix Plus SYBR + FLUORESCEIN (Quantace Ltd., London, UK). Three negative controls (with no template, no reverse transcriptase and no RNA in the reverse transcriptase reaction) were also included in each plate to detect any possible contamination. After a hot start

Table 1 Sequences for forward and reverse primers of the indicated target genes and the size expected for each PCR-amplified product

\begin{tabular}{|c|c|c|c|c|}
\hline Enzyme & Gene symbol & Forward primer & Reverse primer & Amplicon size $(b p)$ \\
\hline APA & ENPEP & 5'-GCTCTCCTTGAACCACAAGACA-3' & 5'-TTCTCTTCCCTITGAGATACTTGG-3' & 133 \\
\hline \multicolumn{5}{|l|}{ Housekeeping Gene name } \\
\hline$\beta$-actin & ACTB & 5'-TCCCTGGAGAAGAGCTACGA-3' & 5'-ATCTGCTGGAAGGTGGACAG-3' & 362 \\
\hline $\begin{array}{l}\text { Succinate dehydrogenase } \\
\text { complex, subunit A }\end{array}$ & SDHA & 5'-TCTGCCCACACCAGCACT-3' & 5'-CCTCTCCACGACATCCTTCC-3' & 142 \\
\hline TATA box binding protein & $T B P$ & $5^{\prime}-\mathrm{GGATAAGAGAGCCACGAACCAC-3^{ \prime }}$ & 5'-TTAGCTGGAAAACCCAACTTCTG-3' & 139 \\
\hline Peptidylpropyl isomerase A & PPIA & 5'-GGTCCCAAAGACAGCAGAAAA-3' & 5'-TCACCACCCTGACACATAAACC-3' & 114 \\
\hline
\end{tabular}

Primers for the assayed housekeeping genes are also shown. 

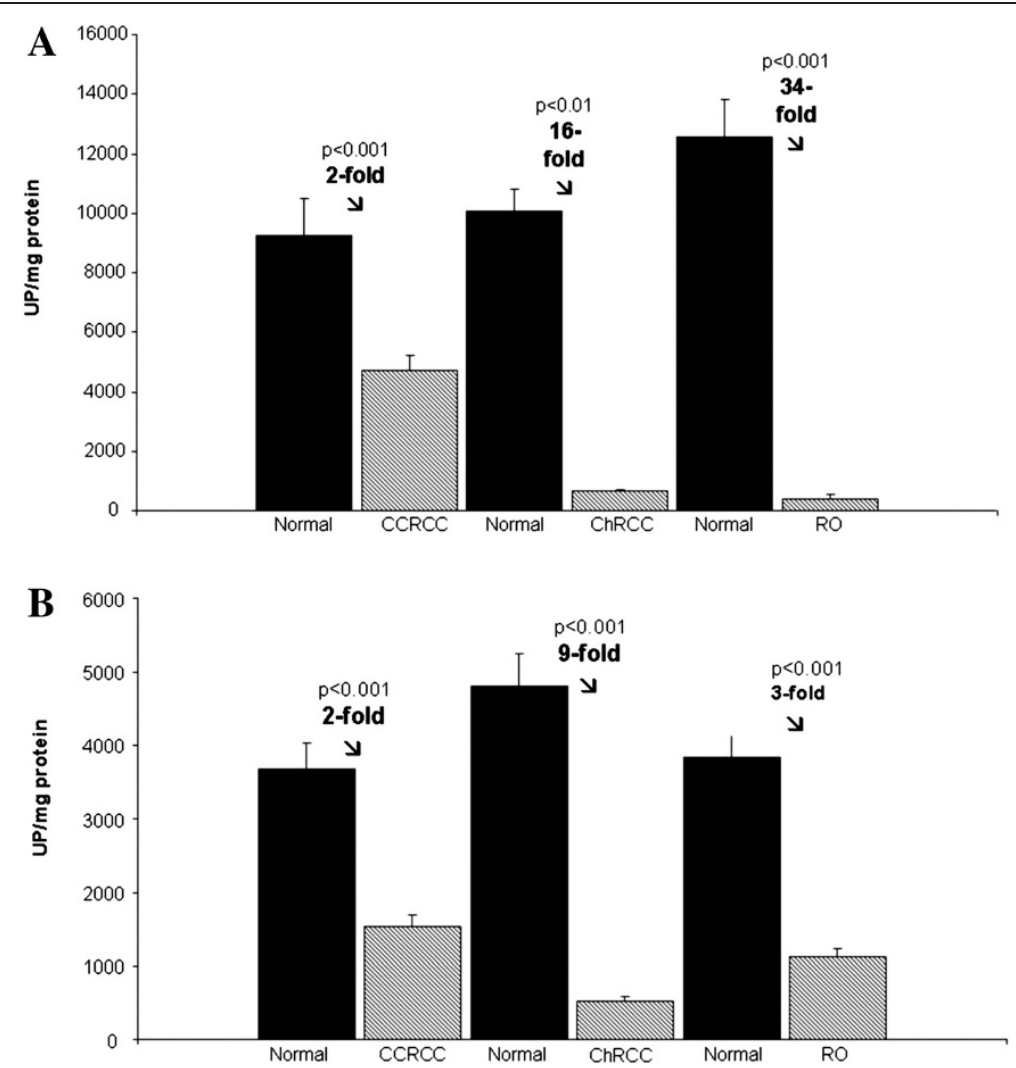

Figure 1 Glutamyl-aminopeptidase activity profile in the membrane-bound (A) and soluble fraction (B) of CCRCC, ChRCC and RO.

The columns compare tumour with non-tumour surrounding tissue (normal). Values represent mean $\pm \mathrm{SE}$ of enzyme activities recorded as units of enzyme per milligram of protein (U/mg prot). Mann-Whitney test: $\left.\left(^{* *}\right) P<0.001 ;{ }^{* *}\right) P<0.01$.

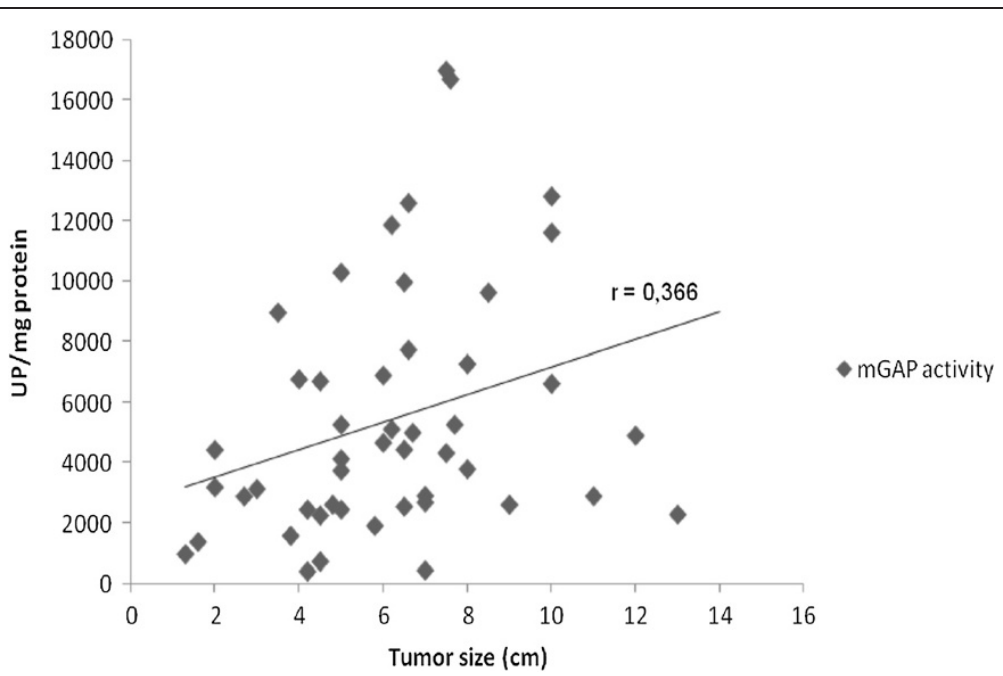

Figure 2 Representation of the correlation between membrane-bound gultamyl-aminopeptidase and tumour size in CCRCC. Values represent mean \pm SE of enzyme activities recorded as units of enzyme per milligram of protein (U/mg prot). Spearman's rank test: coefficient $(r)=0.366 ; P<0.05$. 
$\left(10 \mathrm{~min}\right.$ at $\left.94^{\circ} \mathrm{C}\right)$, the parameters used for PCR amplification were: $10 \mathrm{~s}$ at $94^{\circ} \mathrm{C}, 20 \mathrm{~s}$ at $60^{\circ} \mathrm{C}$ and $30 \mathrm{~s}$ at $72^{\circ} \mathrm{C}$, for 50 cycles.

Real-time PCR data were expressed as the fold change of the target gene expression relative to the geometric mean (g.m.) mRNA expression of the housekeeping genes in each sample, as described by Vandesompele et al. [31]. The fold change in gene expression was calculated by the formula: $2_{\mathrm{T}}^{-\Delta \Delta \mathrm{C}}$, where $\mathrm{C}_{\mathrm{T}}$ is the threshold cycle, as calculated by the iCycler software, $\Delta \mathrm{C}_{\mathrm{T}}=$ $\left(\mathrm{C}_{\mathrm{T}}\right.$ target gene $-\mathrm{C}_{\mathrm{T}}$ g.m.reference genes) and $\Delta \Delta \mathrm{C}_{\mathrm{T}}=$ $\left(\Delta \mathrm{C}_{\mathrm{T}}\right.$ test sample $-\Delta \mathrm{C}_{\mathrm{T}}$ control sample).

CCRCCs with different Fuhrman's gade and stage (low and high) were always measured in the same analytical run to exclude inter-run variations..

\section{Statistical analysis}

SPSS $^{\odot} 19.0$ software (IBM, Madrid, Spain) was used to perform statistical data analysis. A Kolmogorov-Smirnov test was applied to data obtained from tissue to determine whether the numbers followed or not a normal distribution. Based on this information $(\mathrm{p}<0.05)$, data from GAP activity and mRNA levels were analysed with non parametric tests. Mann-Whitney test was used to detect differences between non-tumour and tumour tissues, and between CCRCCs with different Fuhrman's grade [G1/2 (low) vs. G3/4 (high)] and stage [pT1/2 (organ confined) vs. pT3/4 (non-organ confined)]. Spearman's correlation ( $\rho$ ) test was performed to evaluate the correlation between GAP activity, patient age and gender, and tumour size of CCRCC. A value of $P<0.05$ was considered statistically significant. Finally, overall survival (five years) was assessed by the Kaplan-Meier method and compared by log-rank test according to GAP activity levels.

\section{Results}

Glutamyl-aminopeptidase activity profile in renal tumours Data obtained in the GAP activity assays across the different tumour types and in stratified CCRCC are reported in Figures 1 and 2.

Table 2 Membrane-bound and soluble GAP activity in CCRCC stratified by grade and stage

\begin{tabular}{lccc}
\hline $\mathbf{a}$ & & & \\
& & & \\
mGAP & $6099 \pm 1689$ & High Grade (G3-G4) & $P$ \\
sGAP & $\mathbf{1 1 9 3} \pm \mathbf{2 3 1}$ & $\mathbf{1 8 9 5} \pm \mathbf{2 1 3}$ & ns \\
$\mathbf{b}$ & Low Stage (T1-T2) & High Stage (T3-T4) & P \\
mGAP & $6322 \pm 1169$ & $5699 \pm 893$ & ns \\
sGAP & $1563 \pm 210$ & $1693 \pm 310$ & ns \\
\hline
\end{tabular}

Values are means \pm SE of Units per $\mathrm{mg}$ of protein (U/mg Prot). Abbreviations: ns not significant. Statistically significant results are in bold.
Figure 1 shows GAP activity measured in tumour and non-tumour tissue (normal) of CCRCC, ChRCC and RO patients. Activity was recorded as pmol of product $/ \mathrm{min} /$ $\mathrm{mg}$ protein (UP/mg protein) and is presented as mean \pm $\mathrm{SE}$. As shown in Figure 1A, when compared with nontumour tissues, membrane-bound GAP activity decreased significantly in CCRCC (two-fold) (Mann-Whitney test, $P<0.001)$, and drastically in ChRCC (16-fold, $P<0.01$ ) and RO (34-fold, $P<0.001)$. The soluble GAP activity in
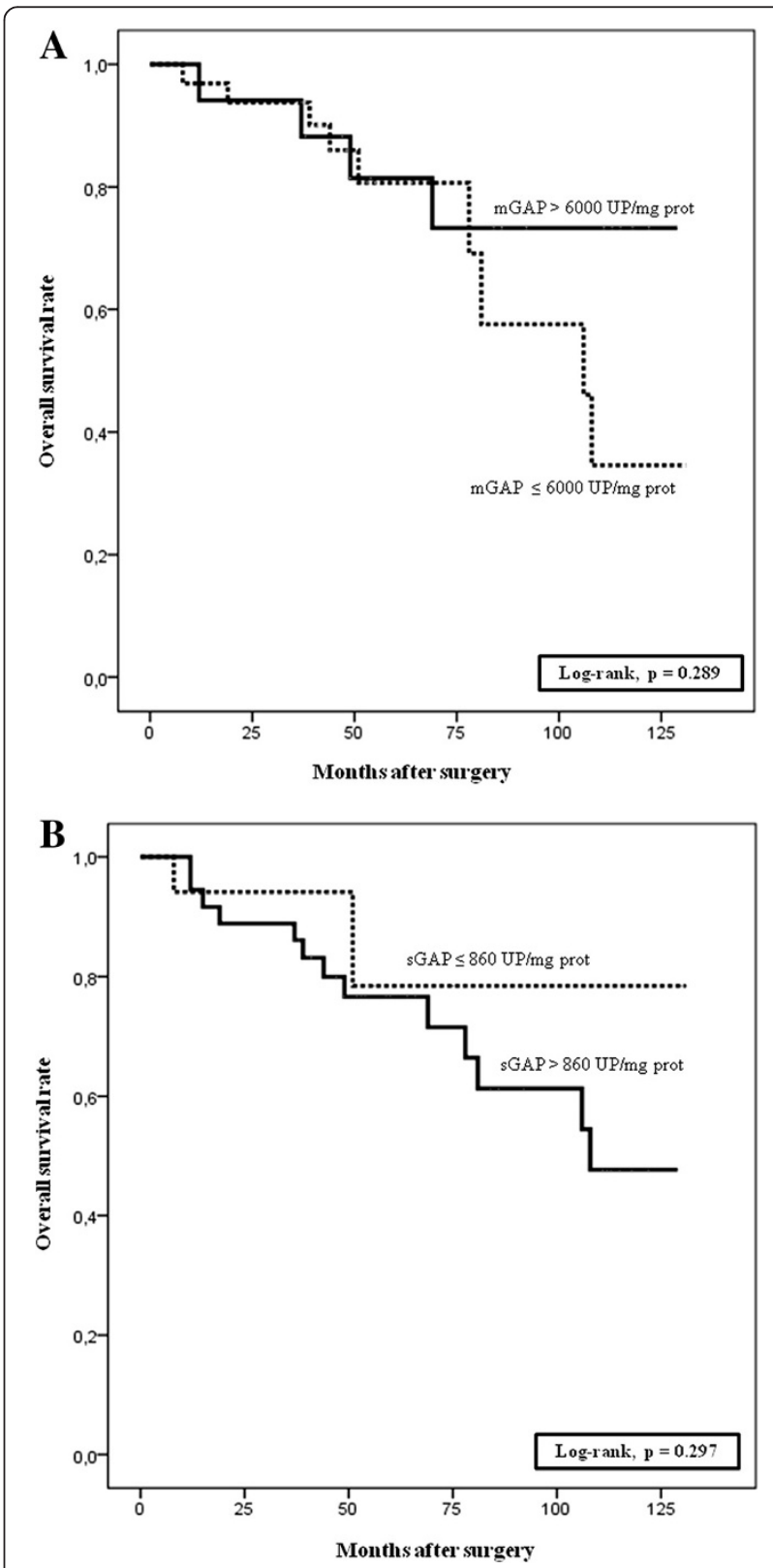

Figure 3 Patient survival curves according to the membrane-bound (A) and soluble (B) glutamyl-aminopeptidase activity levels (Kaplan-Meier method). GAP activity did not significantly impact in survival of patients with CCRCC (log-rank p > 0.05). 
renal tumours (Figure 1B) also decreased significantly in all tumour types analysed when compared with normal tissue samples $(P<0.001)$.
Table 2 represents GAP activity in the different grades and stages of CCRCC group (Low grade: G1-G2, $\mathrm{n}=24$ vs. High grade: G3-G4, $\mathrm{n}=26$; Low stage: T1-T2, $\mathrm{n}=34$
A
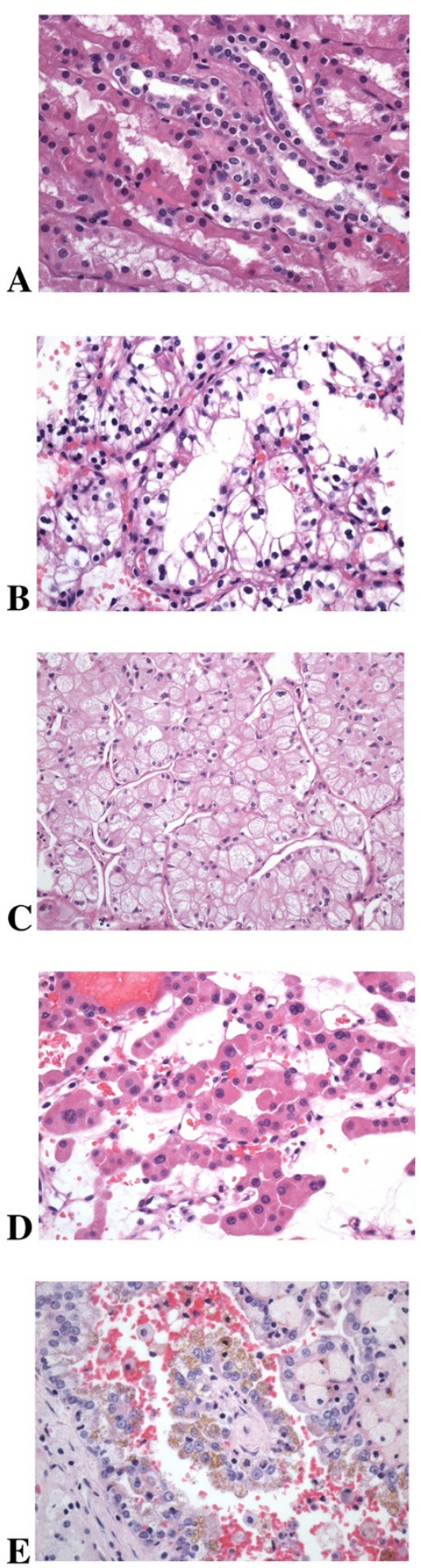
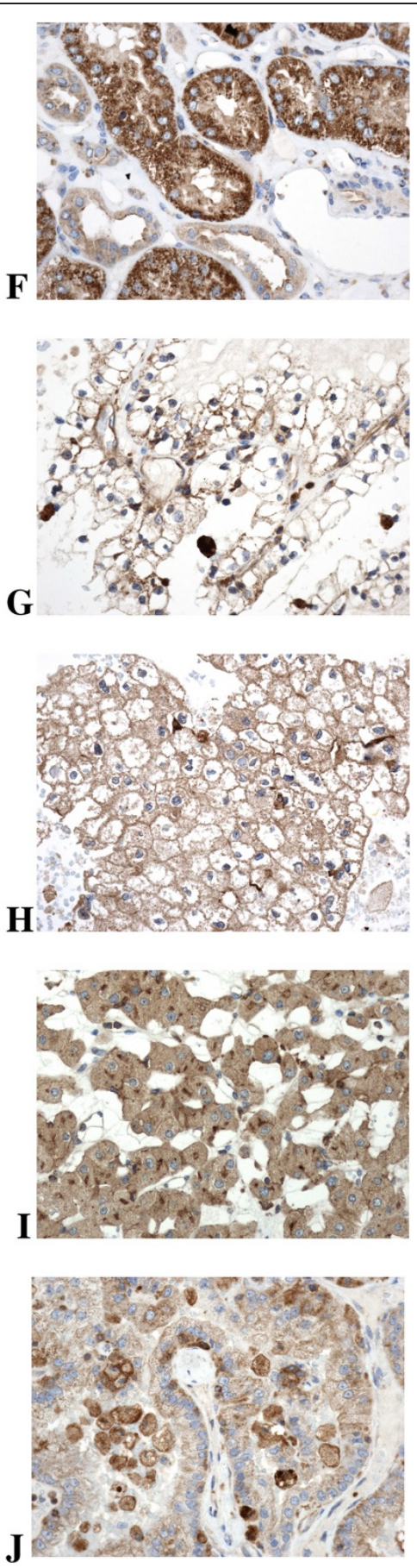

Figure 4 Immunohistochemistry of GAP in renal tumours. Haematoxylin and Eosin (HE) staining of (A) normal renal tissue, (B) clear cell renal cell carcinoma, (C) chromophobe renal cell carcinoma, (D) renal oncocytoma and (E) papillary renal cell carcinoma, and their respective GAP immunostainings in the right column. (F) Immunostaining appears intense in proximal convoluted tubules and is mild to moderate in collecting ducts, (G) mild delineating cytoplasmic membranes in clear cell renal cell carcinoma, mild membranous and cytoplasmic in (H) chromophobe renal cell carcinoma and (I) renal oncocytoma, and $(\mathbf{J})$ mild in papillary renal cell carcinoma (GAP immunostaining, haematoxylin counterstaining, original tissue magnification $\times 200$ ). 
vs. High stage: T3-T4, $\mathrm{n}=16)$. Activity was recorded as $\mathrm{pmol}$ of product $/ \mathrm{min} / \mathrm{mg}$ protein (UP/mg protein) and is presented as mean $\pm \mathrm{SE}$.

After stratification by grade, soluble GAP showed higher activity in CCRCCs with a high Furhman's grade in comparison to those clear cell carcinomas in a lower grade (Mann-Whitney test, $P<0.05$ ). Analyses of grading for membrane-bound GAP and staging for both soluble and membrane-bound GAP activities were not statistically significant.

The correlation study demonstrated that membranebound GAP activity is positively correlated with tumour size in CCRCC samples (Spearman's rank test, $P<0.05$ ) (Figure 2).

Finally, Kaplan-Meier curves revealed that GAP activity was not correlated with patients' five-year survival $(\log$-rank test $P>0.05)$ (Figure $3 \mathrm{~A}$ and $\mathrm{B}$ ).

\section{Glutamyl-aminopeptidase immunohistochemical expression}

Figure 4 shows the immunohistochemical results in nontumour and tumour tissue. The pattern of staining of each tumour subtype coincided fully in every case. GAP immunostaining was strongly positive in proximal convoluted tubules in non-tumour renal tissue and slightly positive in distal tubules. CCRCC showed diffuse and mild membrane immunostaining. PRCC also showed positive immunoreaction located in cytoplasmic membranes, but the pattern of staining was focal. Both ChRCC and RO shared the same immunohistochemical expression with mild and diffuse cytoplasmic staining.

\section{GAP (ENPEP) mRNA levels and CCRCC aggressiveness}

Table 3 shows the ENPEP mRNA levels in CCRCCs with different Fuhrman's grade [G1/2 (low) vs. G3/4 (high)] and stage $[\mathrm{pT} 1 / 2$ (organ confined) vs. pT3/4 (non-organ confined)]. ENPEP mRNA levels were higher in low grade CCRCCs than in high grade tumours (Table 3a), however, this result was not statistically significant (Mann-Whitney test $\mathrm{p}=0.322$ ). Organ confined CCRCCs showed similar ENPEP mRNA levels to non-organ confined tumours (Table 3b) $(\mathrm{p}=0.856)$.

Table 3 GAP (ENPEP) mRNA levels in CCRCC

\begin{tabular}{lccc}
\hline a & Low Grade (G1-G2) & High Grade (G3-G4) & $P$ \\
ENPEP & $1065 \pm 347$ & $479 \pm 138$ & ns \\
b & & & \\
& Low Stage (T1-T2) & High Stage (T3-T4) & $P$ \\
ENPEP & $707 \pm 185$ & $818 \pm 383$ & ns \\
\hline
\end{tabular}

qRT-PCR data for each analysed sample are recorded as relative units. Values are means \pm SE. ns: Not significant (Mann-Whitney test).

\section{Discussion}

Many studies have revealed that peptidases are involved in several physiological functions and play a key role in growth control, differentiation, and signal transduction of several cell systems [31]. Altered expression and catalytic function patterns of these enzymes may contribute to neoplastic transformation and tumour progression $[31,32]$. Regarding kidney tumours, the altered expression and activity of several peptidases have been evaluated in previous studies [8-10,33-36]. Therefore, the study of peptidase expression and activity appears to be a promising field in the quest for new renal tumour markers and targets. For instance, some studies have led to the design of clinical diagnostic tools, such us neprylisin (NEP/CD10), which is a useful immunohistochemical marker in the diagnosis of proximal nephron-derived carcinomas [33].

In this study we analysed the activity and the expression of a renal cell marker, GAP (or gp160), in a subset of renal tumours and in their non-tumour adjacent tissues. GAP activity of both membrane-bound and soluble fractions was markedly decreased in all tumour subtypes when compared with normal tissues. Interestingly, the decrease in membrane-bound GAP activity revealed a gradient along the different phenotypes of renal neoplasms. Thus, while the activity was twice lower in CCRCC than in normal tissue, the decrease in ChRCC and RO was 16-fold and 34-fold respectively. In addition, we recently demonstrated that this enzyme's activity decreased 8-fold in PRCC [35]. This finding is similar to some others measuring alternative relevant peptidases, and supports the hypothesis that the loss of several physiologically significant peptidases may be a critical step in the malignant transformation of renal tissues [8,10-12,17,35].

In terms of immunohistochemistry, GAP was strongly expressed in the membrane of proximal tubule cells, whereas tumours from this origin showed only a mild membrane positivity (CCRCC) or even very weak staining (PRCC). This result is in accordance with previous works $[8,9]$ and suggests that the decreases of membrane-bound GAP activity in these neoplasms could be due to loss of protein expression. In addittion, we observed a mild diffuse GAP immunostaining in ChRCC and RO. This pattern is expected for both tumours as they originate from the distal nephron [2]-a specific topography with mild to negative GAP expression, as also shown in other reports $[9,15]$.

Our previous studies demonstrated that several aminopeptidase activities are significantly increased in high stage and high grade CCRCCs $[11,12,29,31]$ and correlated with patient 5-year survival [37], suggesting that these proteases may be a predictor of poor outcome in this disease. In the present work, GAP activity was not found to be correlated with CCRCC patient survival. 
However, soluble GAP activity significantly increased in high grade (G3-G4) CCRCCs and membrane-bound GAP activity was positively correlated with tumour size, indicating that this peptidase is probably involved in CCRCC growth and aggressiveness.

GAP mRNA levels in renal tumours are similar or even higher than in normal renal tissue $[10,11]$. In the present work, we observed differences among CCRCCs with low and high Furhman grades, although this result did not reach statistical significance. Similar discrepancies between mRNA expression and enzyme activity or expression have been recently reported in renal carcinomas and in other non-neoplastic kidney diseases when other peptidases were measured [34,38,39]. This finding indicates that these protein modifications could occur at a postranscriptional level and illustrates the importance of assesing protein changes through various means, and not relying solely on mRNA levels [38].

The exact role that GAP plays in renal neoplasms still remains to be clarified. This enzyme has been reported to play a functional role as a regulator of angiotensin IImediated tumour growth and invasiveness via conversion of locally produced angiotensin II (ang II) in several solid tumours [40]. The downregulation of GAP and other angiotensin-converting peptidases observed in this study and in others $[8-11,34]$ suggests an imbalance in the metabolism of intrarenal angiotensins. However, it is difficult to ascertain which one of these bioactive peptides is more affected in renal neoplasms. We recently showed an important neoexpression of endothelial angiotensinconverting enzyme (ACE) in renal cancer [34], what suggests a higher synthesis of tumour vessel ang II, a vasoactive hormone whose local long-term actions are related to angiogenesis in proliferative disorders [41,42]. Although GAP has been proposed as a functional vascular target in pathologic angiogenic processes [43], this study could not find any GAP neoexpression in renal neoplasm blood vessels. Since this enzyme converts angiotensin II to III, this result could strengthen the hypothesis of an accumulation of ang II in renal tumour vessels, which could stimulate angiogenesis.

GAP has been commonly described as a membranebound peptidase, but the activity of soluble isoforms has also been reported in normal and tumour tissues [21-23]. Our data in renal neoplasms have shown distinct patterns of activity in the two subcellular fractions analysed. However, the soluble GAP activity profile was similar to that previously reported with the cytosolic aspartylaminopeptidase (EC. 3.4.11.21) in these tumours [10,11]. Therefore, further studies are required to clarify the presence of a soluble isoform of GAP in renal tissues.

In this context, the role of soluble peptidases in the regulation of proliferative diseases is less clear than that of membrane-bound peptidases. Nevertheless, recent findings suggest that a number of peptides and hormones, commonly called "intracrine", act in the intracellular space after either internalisation or retention in their cells of synthesis $[44,45]$. Furthermore, intracellular angiotensin II has been reported to also induce cell proliferation in several tissues [44-47]. Therefore, the idea of an intracrine angiotensin dysregulation in kidney tumours should not be ruled out.

\section{Conclusions}

This study demonstrates marked decreases in activity and mild to weak expression of GAP in the four most common histological subtypes of renal neoplasms (CCRCC, PRCC, ChRCC and RO), and a positive correlation between the soluble GAP and CCRCC aggressiveness. These results favour the possibility of a metabolic imbalance among intrarenal angiotensins and a role of GAP in renal neoplastic diseases. A better understanding of the pathophysiological role of GAP in these proliferative disorders will be helpful for designing effective diagnostic, prognostic and therapeutic tools for renal neoplasms.

\section{Abbreviations}

GAP: Glutamyl-aminopeptidase; RCCs: Renal cell carcinomas; CCRCC: Clear cell renal cell carcinoma; PRCC: Papillary renal cell carcinoma; ChRCC: Chromophobe renal cell carcinoma; RO: Renal oncocytoma; UP: Units of peptidase, pmol of product/min

\section{Competing interests}

All the authors declare no competing interests.

\section{Authors' contributions}

GL, LB and JIL: research conception and design, edition, revision and approval of the final version. GL, LC and JG: statistical analysis. LB, CES, BS and IP: sample preparation, enzyme assays and protein determinations. FMP, MLC, LB and IP: qRT-PCR assays. JIL: provision of the surgical material and clinical follow-up data of the patients. JIL: selection of appropriate material for immunohistochemical analysis and interpretation of the obtained results. BS and IP: prepared figures and table. GL, LC, LB and JIL: collection and interpretation of final results. All authors read and approved the final manuscript.

\section{Acknowledgements}

We wish to thank Arantza Pérez (UPV/EHU) for her technical contribution to this study. The authors also thank Ana Abascal, Alicia Esteve and Mar Gonzalez, lab technicians at the Department of Pathology, Cruces University Hospital, for their excellent immunohistochemical work. This work was supported by grants from the Basque Government (IT8-11/13), the University of the Basque Country UPV/EHU (UFI 11/44, EHUA 12/15) and the Gangoiti Barrera Foundation. We want to particularly acknowledge the patients enrolled in this study for their participation and the Basque Biobank for Research-OEHUN for this collaboration.

\section{Author details}

${ }^{1}$ Department of Physiology, Faculty of Medicine and Dentistry, Universitiy of the Basque Country (UPV/EHU), Leioa, Bizkaia, Spain. ${ }^{2}$ Department of Nursing I, Faculty of Nursing, Universitiy of the Basque Country (UPV/EHU), Leioa, Bizkaia, Spain. ${ }^{3}$ Institute for Chemical Research, CSIC, Sevilla, Spain.

${ }^{4}$ Department of Anatomic Pathology, Cruces University Hospital, University of the Basque Country (UPV/EHU), Barakaldo, Bizkaia, Spain.

Received: 23 June 2013 Accepted: 8 May 2014

Published: 30 May 2014

\section{References}

1. Siegel R, Naishadham D, Jemal A: Cancer statistics, 2013. CA Cancer J Clin 2013, 63(1):11-30. 
2. López-Beltrán A, Scarpelli M, Montironi R, Kirkali Z: 2004 WHO classification of the renal tumors of the adults. Eur Urol 2006, 49(5):798-805.

3. Schuetz NA, Yin-Goen Q, Amin MB, Moreno CS, Cohen C, Hornsby CD, Yang WL, Petros JA, Issa MM, Pattaras JG, Ogan K, Marshall FF, Young AN: Molecular classification of renal tumors by gene expression profiling. J Mol Diagn 2005, 7(2):206-208.

4. Lam JS, Shvarts O, Leppert JT, Figlin RA, Belldegrun AS: Renal cell carcinoma 2005: new frontiers in staging, prognostication and targeted molecular therapy. J Urol 2005, 173(6):1853-1862.

5. Jin JS, Hsieh DS, Lin YF, Wang JY, Sheu LF, Lee WH: Increasing expression of extracellular matrix metalloprotease inducer in renal cell carcinoma: tissue microarray analysis of immunostaining score with clinicopathological parameters. Int J Urol 2006, 13(5):573-580.

6. Patraki E, Cardillo MR: Quantitative immunohistochemical analysis of matrilysin 1 (MMP-7) in various renal cell carcinoma subtypes. Int J Immunopathol Pharmacol 2007, 20(4):697-705.

7. Catania JM, Chen G, Parrish AR: Role of matrix metalloproteases in renal pathophysiologies. Am J Physiol Renal Physiol 2007, 292(3):905-911.

8. Göhring B, Holzhausen HJ, Meye A, Heynemann H, Rebmann U, Langner J, Riemann D: Endopeptidase 24.11/CD10 is down-regulated in renal cell cancer. Int J Mol Med 1998, 2(4):409-414.

9. Nanus DM, Bogenrieder T, Papandreou CN, Finstad CL, Lee A, Vlamis V: Aminopeptidase $\mathrm{A}$ expression and enzymatic activity in primary human renal cancers. Int J Oncolology 1998, 13(2):261-267.

10. Varona A, Blanco L, López Jl, Gil J, Agirregoitia E, Irazusta J, Larrinaga G: Altered levels of acid, basic, and neutral peptidase activity and expression in human clear cell renal cell carcinoma. Am J Physiol Renal Physiol 2007, 292(2):780-788.

11. Blanco L, Larrinaga G, Pérez I, López Jl, Gil J, Agirregoitia E, Varona A: Acid, basic and neutral peptidases present different profiles in chromophobe renal cell carcinoma and in oncocytoma. Am J Physiol Renal Physiol 2008, 294(4):850-858

12. Varona A, Blanco L, Perez I, Gil J, Irazusta I, Lopez JI, Candenas ML, Pinto FM, Larrinaga G: Expression and activity profiles of DPP IV/CD26 and NEP/CD10 glycoproteins in the human renal cancer are tumor-type dependent. BMC Cancer 2010, 10:193.

13. Wolf $G$, Mentzel $S$, Assmann $\mathrm{K}$ : Aminopeptidase $A$ : a key enzyme in the intrarenal degradation of angiotensin II. Experimental Nephrolology 1997, 5(5):364-369.

14. Dijkman HB, Assmann KJ, Steenbergen EJ, Weltzels JF: Expression and effect of inhibition of aminopeptidase-A during nephrogenesis. J Histochemestry and Cytochemestry 2006, 54(2):253-262.

15. Bander NH, Cordon-Cardo C, Finstad CL, Whitmore WF, Vaughan ED, Oettgen HF, Melamed M, Old LJ: Immunohistologic dissection of the human kidney using monoclonal antibodies. J Urol 1985, 133(3):502-505

16. Nanus DM, Engelstein D, Gastl GA, Gluck L, Vidal MJ, Morrison M, Finstad C, Bander NH, Albino AP: Molecular cloning of the human kidney differentiation antigen gp160: Human aminopeptidase A. Proc Natl Acad Sci U S A 1993, 90(15):7069-7073.

17. Kehlen A, Göhring B, Langer J, Riemann D: Regulation of the expression of aminopeptidase A, aminopeptidase N/CD13 and dipeptidylpeptidase IV/ CD26 in renal carcinoma cells and renal tubular epithelial cells by cytokines ans CAMP-increasing mediators. Clin Exp Immunol 1998, 111(2):435-441.

18. Nanus DM, Pfeffer LM, Bander NH, Bahri S, Albino AP: Antiproliferative and antitumor effects of alpha interferon in renal cell carcinomas: correlation with the expression of a kidney associated differentiation glycoprotein. Cancer Res 1990, 50(14):4190-4194.

19. Sobin LH, Wittekind C: TNM Classification of Malignant Tumors. 6th edition. New York: Wiley-Liss; 2002

20. Furhman SA, Lasky LC, Limas C: Prognostic significance of morphologic parameters in renal cell carcinoma. Am J Surg Pathol 1982, 6(7):655-663.

21. Martínez JM, Prieto I, Ramírez MJ, Cueva C, Alba F, Ramírez M: Aminopeptidase activities in breast cancer tissue. Clin Chem 1999, 45(10):1797-1802

22. Ramírez-Expósito MJ, Martínez JM, Prieto I, Alba F, Ramírez M: Comparative distribution of glutamyl and aspartyl aminopeptidase activities in mouse organs. Horm Metab Res 2000, 32(5):161-163.

23. Ramírez M, Prieto M, Alba F, Vives F, Banegas I, de Gasparo M: Role of central and peripheral aminopeptidase activities in the control of blood pressure: a working hypothesis. Heart Fail Rev 2008, 13(3):339-353.

24. Tobe H, Kojima F, Aoyagi T, Umezawa H: Purification using amastatin and properties of aminopeptidase A from pig kidney. Biochimica Biophysica Acta 1980, 613(2):459-468.
25. Bradford MM: A rapid and sensitive method for the quantitation of microgram quantities of protein utilizing the principle of protein-dye binding. Anal Biochem 1976, 72:248-254.

26. Patak E, Candenas ML, Pennefather JN, Ziccone S, Lilley A, Martín JD, Flores C, Flores C, Mantecón AG, Story ME, Pinto FM: Tachykinins and tachykinin receptors in human uterus. Br J Pharmacol 2003, 139(3):523-532.

27. Rozen S, Skaletsky H: Primers on the WWW for general users and for biologist programmers. Methods Mol Biol 2000, 132:365-368.

28. Jung M, Ramankulov A, Roigas J, Johannsen M, Ringsdorf M, Kristiansen G, Jung $\mathrm{K}$ : In search of suitable reference genes for gene expression studies of human renal cell carcinoma by real-time PCR. BMC Mol Biol 2007, 8:47.

29. Radonic A, Thulke S, Mackay IM, Landt O, Siegert W, Nitsche A: Guideline to reference gene selection for quantitative real-time PCR. Biochem Biophys Res Commun 2004, 313(4):856-862.

30. Pinto FM, Almeida TA, Hernandez M, Devillier P, Advenier C, Candenas ML: mRNA expression of tachykinins and tachykinin receptors in different human tissues. Eur J Pharmacol 2004, 494(2-3):233-239.

31. Antczak C, De Meester I, Bauvois B: Ectopeptidases in pathophysiology. Bioessays 2001, 23(3):251-260.

32. Carl-McGrath S, Lendeckel U, Ebert M, Röcken C: Ectopeptidases in tumour biology: a review. Histol Histopathol 2006, 21(12):1339-1353.

33. Zhou M, Roma A, Magi-Galluzzi C: The usefulness of immunohistochemical markers in the differential diagnosis of renal neoplasms. Clin Lab Med 2005, 25(2):247-257.

34. Larrinaga G, Perez I, Sanz B, Blanco L, López Jl, Candenas ML, Pinto FM, Gil J, Irazusta J, Varona A: Angiotensin-converting enzymes (ACE and ACE2) are downregulated in renal tumors. Regul Pept 2010, 165(2-3):218-223.

35. Blanco L, Perez I, Sanz B, Gil J, López JI, Ugalde A, Varona A, Larrinaga G: Changes in cell-surface peptidase activity in papillary renal cell carcinoma. Anticancer Res 2010, 30(4):1137-1141.

36. Larrinaga G, López JI, Casis L, Blanco L, Gil J, Agirregoitia E, Varona A: Cystinyl aminopeptidase activity is decreased in renal cell carcinoma. Regul Pept 2007, 144(1-3):56-61.

37. Larrinaga G, Blanco L, Sanz B, Perez I, Gil J, Unda M, Andrés L, Casis L, López Jl: The impact of peptidase activity on clear cell renal cell carcinoma survival. Am J Physiol Renal Physiol 2012, 303(12):1584-1591.

38. Kasinath BS, Mariappan MM, Sataranatarajan K, Lee MJ, Feliers D: mRNA traslation: unexplored territory in renal science. J Am Soc Nephrol 2006, 17(12):3281-3292.

39. Wysocki J, Ye M, Soler MJ, Gurley SB, Xiao HD, Bernstein KE, Coffman TM, Chen S, Battle D: ACE and ACE2 activity in diabetic mice. Diabetes 2006, 55(77):2132-2139.

40. Ino K, Shibata K, Kajiyama H, Kikkawa F, Mizutani S: Regulatory role of membrane-bound peptidases in the progression of gynecologic malignancies. Biol Chem 2004, 385(8):683-690

41. Deshayes F, Nahmias C: Angiotensin receptors: a new role in cancer? Trends Endocrinol Metab 2005, 16(7):293-299.

42. George AJ, Thomas WG, Hannan RD: The renin-angiotensin system and cancer: old dog, new trick. Nat Rev Cancer 2010, 10(11):745-759.

43. Marchiò $S$, Lahdenranta J, Schlingemann RO, Valdembri $D$, Wesseling $P$, Arap MA, Hajitou A, Ozawa MG, Trepel M, Giordano RJ, Nanus DM, Dijkman $H B$, Oosterwijk E, Sidman RL, Cooper MD, Bussolino F, Pasqualini R, Arap W: Aminopeptidase $\mathrm{A}$ is a functional target in angiogenic blood vessels. Cancer Cell 2004, 5(2):151-162.

44. Re RN, Cook JL: The intracrine hypothesis: an update. Regul Pept 2006, 133(1-3):1-9.

45. Re RN, Cook JL: An intracrine view of angiogenesis. Bioessays 2006 , 28(9):943-953.

46. Baker KM, Chernin MI, Schreiber T, Sanghi S, Heiderzaidi S, Booz GW, Dostal $D$, Kumar R: Evidence of a novel intracrine mechanism in angiotensin II-induced cardiac hypertrophy. Regul Pept 2004, 120(1-3):5-13.

47. Zhuo $\mathrm{J}$, Li XC: New insights and perspectives on intrarenal renin-angiotensin system: fous on intracrine/intracellular angiotensin II. Peptides 2011, 32(7):1551-1565.

doi:10.1186/1471-2407-14-386

Cite this article as: Blanco et al:: Altered glutamyl-aminopeptidase activity and expression in renal neoplasms. BMC Cancer 2014 14:386. 